\title{
From integrated aims to fragmented outcomes: Urban intensification and transportation planning in the Netherlands
}

\author{
Jan Duffhues \\ University of Amsterdam \\ j.duffhues@amsterdam.nl
}

\author{
Luca Bertolini \\ University of Amsterdam \\ I.bertolini@amsterdam.nl
}

\begin{abstract}
Intensification of cities has been a planning aim in many countries over the last decades. A major reason for this is the expectation that urban intensification leads to better accessibility by sustainable transportation modes and therefore contributes to increasing their share. A positive feedback loop exists between the planning of high-capacity transportation networks and intensification of land uses around these transportation networks. Urban intensification policies acknowledge this. However, the integration of transport planning and land-use planning, which one would and should expect as a consequence of this acknowledgement, does not necessarily follow. In the Netherlands, an "implementation gap" in the transport and land-use planning process aimed at urban intensification can be identified, which prevents the positive feedback loop from happening. While similar issues have been identified elsewhere, there is still a lack of knowledge of where in the planning process the implementation gap emerges. This knowledge is essential if the gap is to be closed. To understand this, analysis of various planning documents, interviews, and participant observation are used. The results show that the most critical phases in the planning process are those in which aims need to be translated into actions and actions into performance indicators.
\end{abstract}

\author{
Article history: \\ Received: November 29, 2013 \\ Received in revised form: \\ September 16, 2014 \\ Accepted: January 7, 2015 \\ Available online: August 10, \\ 2015
}

\section{Introduction}

Since 2007, more than half of the world's population has lived in cities. Urban land area has increased by 1.6 to 3.9 percent annually since 1970 (UNEP 2013). To manage this growth in a sustainable way, a growing body of literature supports the notion that a denser, more mixed urban form has a positive effect on travel mode choice and transport energy consumption (Niemeier, Bai, and Handy 2011; Ewing and Cervero 2010; Ewing and Cervero 2001; Brownstone and Golob 2009). This increase in land-use densities and mix, which we call "urban intensification," is also expected to protect natural resources, such as agricultural land and clean air, and to support better use of social services (Hull 2011). However, it has also been noted that without consistent urban transport policies, intensification-related costs (e.g., congestion, pollution) instead of benefits might prevail (Ferreira and Batey 2011; Melia, Parkhurst, and

Copyright 2015 Jan Duffhues \& Luca Bertolini

http://dx.doi.org/10.5198/jtlu.2016.571

ISSN: 1938-7849 | Licensed under the Creative Commons Attribution - Noncommercial License 3.0

The Journal of Transport and Land Use is the official journal of the World Society for Transport and Land Use (WSTLUR) and is published and sponsored by the University of Minnesota Center for Transportation Studies. This paper is also published with sponsorship from WSTLUR and the Institutes of Transportation Studies at the University of California, Davis, and the University of California, Berkeley. 
Barton 2011; Niemeier, Bai, and Handy 2011).

To be able to grasp this complexity and deal with it in an effective way, it is argued that transportation and land-use planning should be carried out in an integrated way (Stead, Geerlings, and Meijers; Hull 2005). However, in practice, transport and land-use integration has to deal with implementation barriers that are difficult to overcome (Banister 2005; Hull 2011). While there is a growing body of knowledge on the nature of these barriers, there is still a lack of knowledge of how they concretely play out in the planning process. Where in the process do they emerge? In what form? This process knowledge seems essential if barriers are to be overcome. In order to shed light on these matters, this paper will explore how transport and land-use (TLU) planning in the Netherlands has dealt with the challenge of urban intensification. First, the concept of "intensification" will be introduced, and it is theorized how this affects TLU planning. Then, the research questions are presented, asking to what extent integrated TLU planning takes place in the Netherlands, how it is implemented, and whether this leads to desirable outcomes. This will be researched through content analysis of Dutch planning documents, informed by in-depth interviews and participant observations, and supported by insights in the specific characteristics of the national context. In the conclusions section, potential implications of the analysis for both the Netherlands and other contexts are drawn. In this respect, the Netherlands can be characterized as a "critical case" in that the implementation gap in this country is also likely to be present in the many countries with a lower, less explicit commitment to urban intensification and TLU planning integration (forr a similar argument applied to sustainable urban development barriers in Oslo and Copenhagen, see Naess, Naess, and Strand 2011, 290)

\section{How intensification affects TLU planning}

The relationships between urban density and mobility are subject to much discussion and are more complex than they at first might seem. Transport and land use influence each other directly and endogenously, but are also affected by exogenous factors such as individual attitudes, socioeconomic and demographic variables, and political preferences (Handy 2002; Krizek and Levinson 2008; Hull 2011). However, there is a broad understanding that a better coordination between transport and land use can contribute to sustainable urban development and lead to more sustainable mobility (Bertolini and le Clercq 2003; Banister 2008; Hull 2011).

Some essential relationships are sketched in Figure 1 below (based on Wegener and Fürst 1999; Bertolini 2012). Land use co-determines the location of human activities. Both firms and households trade off the quality of their present location for the costs (e.g., time, money) needed to reach activities elsewhere (Krizek and Levinson 2008). Individual preferences and possibilities, as determined by socio-demographic, economic, and cultural factors, are important variables in this tradeoff. Grouped together, these individual preferences and possibilities to undertake and reach certain activities are the demand for mobility. This demand can only be met if there is a supply of available transport options. Individual firms and households will have to choose from the available supply of transport options and will choose the option closest to their preferences and within their possibilities. The available transport options are determined by infrastructure investments and transportation planning and policy choices, responding to actual and expected mobility demand but also based on broader considerations (e.g., promoting economic development or social equity, protecting the environment). The available transport options together with the distribution of land uses create accessibility, defined as the ease of reaching the desired activities from other locations. Changes in land use are influenced by accessibility (a more accessible location will be more rewarding to develop), alongside other factors such as the quality of the local environment, available land, and land-use planning policy. This interrelatedness between transport and land use is often conceptualized by means of a "transport land-use (TLU) feedback cycle," as for example discussed in Wegener and Fürst (1999) and Bertolini (2012). 


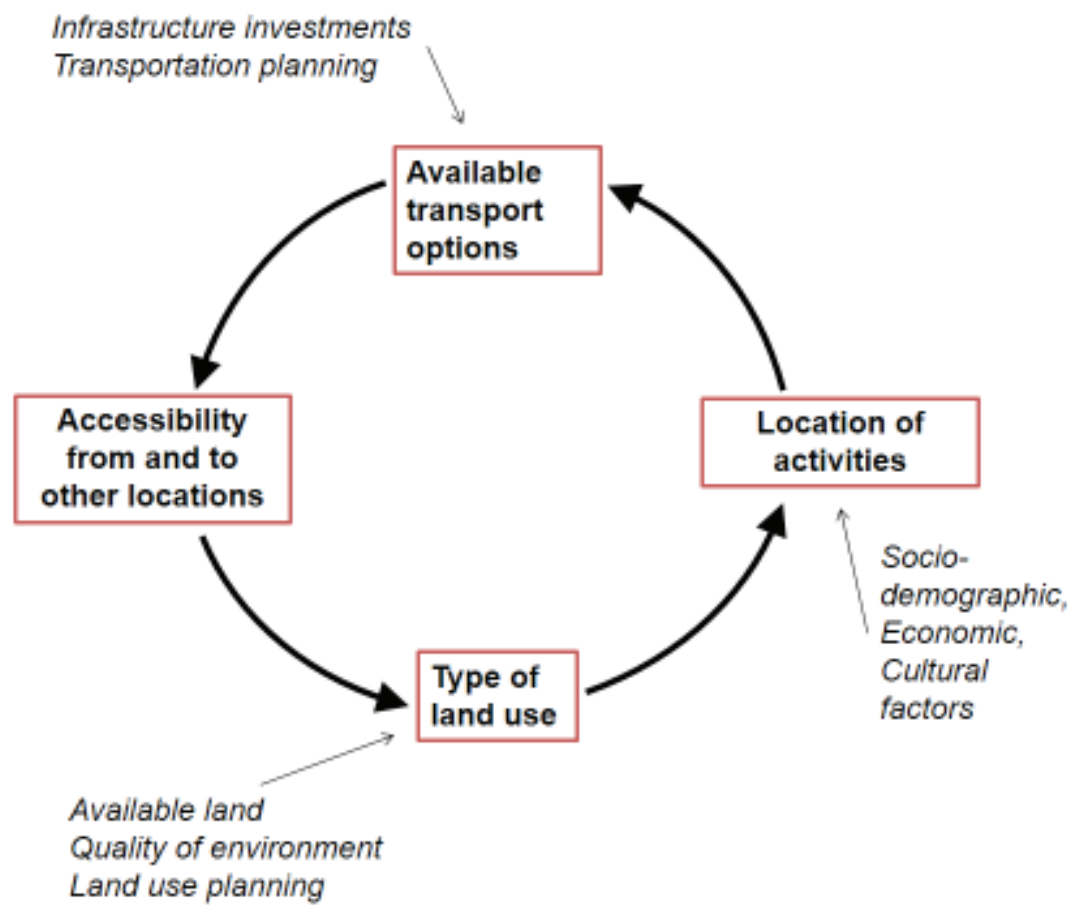

Figure 1: Transport land-use feedback cycle

Intensification is understood in this paper as an increase in activities accessed by both inhabitants and visitors (e.g., commuters, business travelers, tourists) in cities, leading to a more intense use of space by people. Changing land use through urban intensification can lead to a larger number of activities within reach in a constant amount of time. Intensification is expected to have a twofold effect on the TLU feedback cycle: it favors fewer vehicle kilometers traveled and leads to more travel by sustainable transportation modes. (Næss, Strand, et al. 2011a; Næss 2005; Banister 2008; Schwanen, Dieleman, and Dijst 2004).

At the neighborhood level, walking and cycling are expected to take up larger shares as land use is more mixed (Cervero and Duncan 2008) and the neighborhood design encourages walking and cycling to everyday services (Aditjandra, Cao, and Mulley 2012; Ewing and Cervero 2010). Intensification around existing public transportation networks enhances their use (Cervero and Day 2008; Cervero 1998) because this leads to changing activity patterns and modal shift (Geurs et al. 2010). However, intensification can also lead to congestion on the transportation network, which might cause accessibility to decrease and negative externalities to increase because of the concentration of cars and traffic. This is called the "intensification paradox" (Melia, Parkhurst, and Barton 2011). In large cities, this might result in more, not less, traveling because of negative agglomeration effects, causing people and jobs to move farther out (Ferreira and Batey 2011; Wheeler 2009), although this still benefits residents because of increased choice and opportunities (van Wee 2011).

The following intensification/sprawl TLU "feedback cycle" helps to understand these dynamics (see Figure 2). A "TLU intensification feedback cycle" is introduced: Denser and more mixed land use will lead to more activities in the same amount of land, thus intensifying use of the urban area. This also means that the transportation network will be used more intensely, and for short distances in particular. To support intensification, the available transport options need, therefore, to be high-capacity 
slow modes such as walking, cycling, and local and regional public transport. Furthermore, increases in land-use intensity need to occur where the accessibility for those modes is highest. This could lead to a "self-amplifying effect" (Næss, Næss, and Strand 2011) in which intensification makes city areas more attractive and accessible, leading to a higher residential and visitor population within these areas, which becomes a base for further high-capacity and slow transportation network improvements, and so forth.

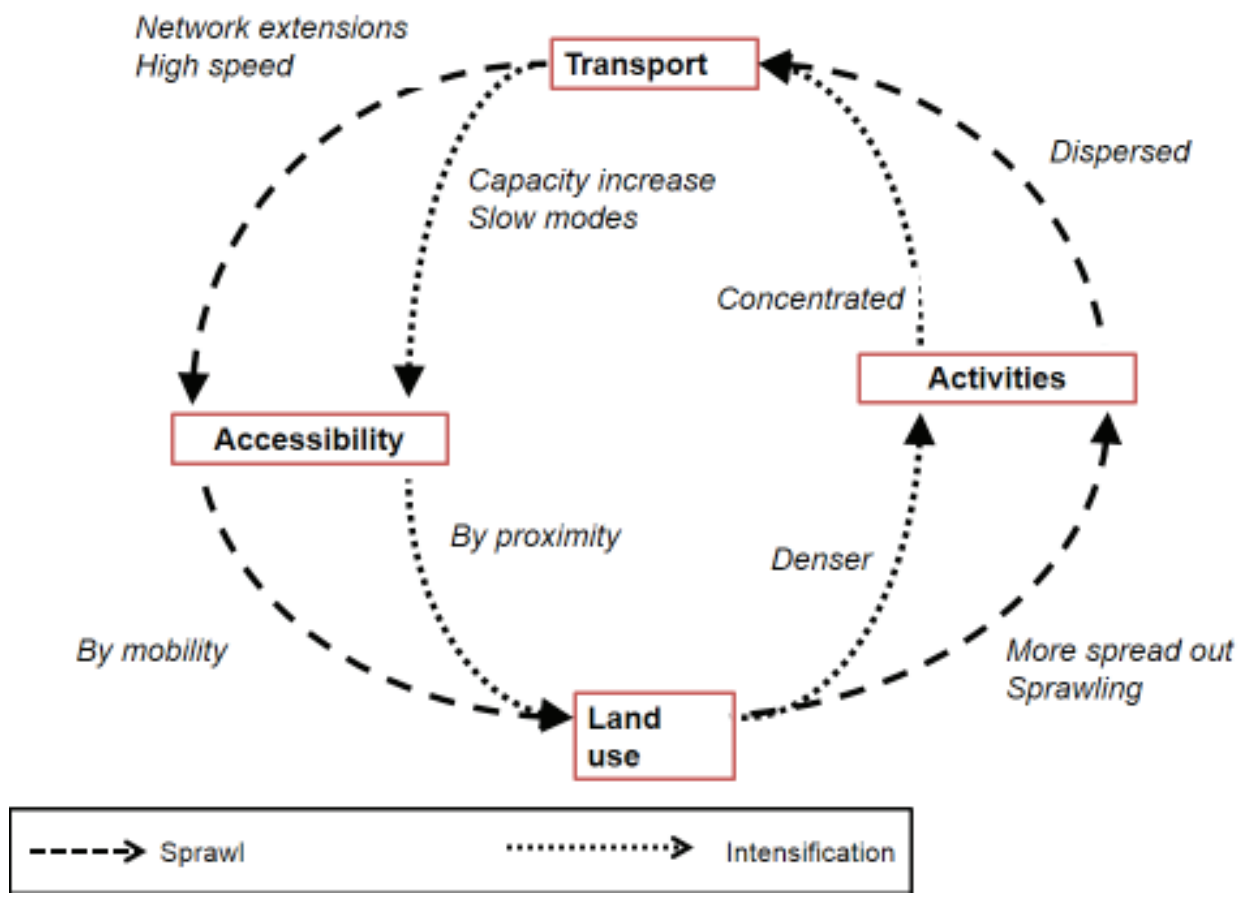

Figure 2: Intensification/sprawl feedback cycle

This can be contrasted with a "TLU sprawl feedback cycle," in which sprawl is defined as a less dense and less mixed land use that leads to more dispersed activities. This is reinforced by transport planning that prioritizes the improvement of high-speed networks (such as highways), leading to an increased accessibility of places farther away from each other, and attracting new activities there. Increased use of these networks will lead to congestion of their most central nodes, which will in turn lead to an increased demand for further network extensions, activity dispersion, and so forth.

A mismatch occurs when land-use planning is directed at intensification while transportation planning is directed at speeding up and extending networks, or conversely when land use is becoming more dispersed while transportation planning is directed at improving slower, high-capacity transportation networks. In the first case, transportation networks will not support the intensive land-use patterns and will instead facilitate land-use sprawl. In the second case, the opposite applies. So, in both cases mismatch transport and land-use planning are weakening, rather than reinforcing, each other. Furthermore, it can be argued that planning for the "intensification feedback cycle" contributes more to sustainable urban development compared to planning for the "sprawl feedback cycle," as argued earlier on.

An important nuance to this line of reasoning is that both ways of reinforcement between transportation and land-use planning are not by necessity alternative, endlessly diverging spirals, leading to ever further intensification or ever more sprawl, but they can also be used to complement each other on the regional scale. For example, on the scale of the city region, dispersion to and intensification of places 
outside of the central city can still contribute to sustainable development for the city region as a whole, preventing further congestion of those parts of the central city already intensively used. This, however, should be a conscious planning choice, taking into account (among other things) the characteristics of the city region, its scale, and its transportation network. Most important, sprawl at the city-region level should still be combined with "intensification" at the neighborhood level, in particular around locations with high public transport accessibility, for instance, in transit-oriented development strategies (Bertolini et al., 2012).

The overarching quest for planners is to match the quality of the accessibility of a given location to the sort of activity to be located there (Bertolini and Le Clercq 2003) so people can reach more opportunities with less, or less harmful mobility (Straatemeier 2008). The TLU feedback cycle can be used to plan for accessibility in an integrative way, acknowledging both the role of mobility, as facilitated by transportation networks, and that of proximity, as facilitated by land uses (Handy 2002). By doing so, shortcomings of the traditional, mobility-focused urban transportation planning can be overcome (Straatemeier 2008), leading to more sustainable development of cities (Bertolini et al. 2005). In the remainder of this paper, we focus on what this would require of TLU planning implementation, and whether this occurs, or doesn't.

\section{Questions and methods}

\subsection{Research question}

Integrated accessibility planning, while conceptually clear, might not be an easy task in practice. When trying to implement plans and policies directed at more transport and land-use integration, institutional barriers arise, causing a gap between the stated goals and the eventual outcomes (Gaffron 2002; Hull 2008, 2011; Stead, Geerlings, and Meijers 2004; Næss, Næss, and Strand 2011). In the literature, much attention has been paid to the different types of barriers (institutional, legal, financial, organizational) and the measures that can bring these barriers down, such as changing financial incentives, improving coordination between policies, and developing better appraisal tools and methods. However, while we have knowledge of the contents of barriers and ways of overcoming them, knowledge about the process in which both might emerge is more limited.

The Randstad Area, the most urbanized part of the Netherlands, is seen as a critical case to provide more understanding of these processes. It can be characterized as a "critical case" in that this implementation gap is also likely to be present in countries with a lower, less explicit commitment to urban intensification and TLU planning integration. This article aims to position the Randstad in relation to the existing work on, among others, Copenhagen (Næss, Strand, et al. 2011b), Oslo (Næss, Strand, et al. 2011b; Næss, Nrss, and Strand 2011) and Perth (Curtis 2008) and to provide an in-depth look at the ways relevant land use and transportation plans address implementation and the measure of success.

This paper looks therefore in detail at the TLU planning process dealing with intensification, from strategic plans to projects, to identify when in the planning and development process these barriers arise. It is expected that this will lead to a better understanding of the causes of the barriers to integrated TLU planning and help better identify the interventions that might prevent the mismatch from happening. For instance, do barriers arise from the outset in strategic plans, during their implementation, or do they become visible only in the set-up and outcomes of specific plans and projects? This paper will try to answer this question through applying the "intensification/sprawl feedback cycle" to analyze the TLU planning and decision-making process regarding intensification in the Netherlands. A mismatch occurs when plans or projects with effects on either the "transport half" or the "land-use half" do not engage with or acknowledge the effects they have on the other half of the cycle. While the findings cannot be 
assumed as valid for other contexts, we believe they can still have a resonance with many of them, and, perhaps most importantly, that the same method of analysis could be fruitfully applied there.

\subsection{Methods}

To be able to identify abstract concepts of when during TLU planning implementation barriers arise, a qualitative content analysis (Bryman 2008) was carried out on all currently ruling "development strategies" and "regional agendas" for the four provinces, four city regions, and four largest municipalities in the Randstad area. The Randstad area is the most urbanized part of the country. These were development strategies for the provinces of North Holland, South Holland, and Utrecht, the city region of The Hague and the city of Amsterdam (see table 2).

These documents were coded using categories relating to the intensification feedback cycle for the stated aims and objectives of the mentioned strategy, the policy measures or other types of implementation tools, and the ways goals are measured or monitored (Pedersen et al. 2009; Timms 2011).

Goals, projects/actions and measures were categorized as follows:

1. Conducive to the intensification of land use

2. Conducive to increasing the share of sustainable transportation modes (public transport, biking, walking)

3. Conducive to intensification of land use and increase of sustainable transportation modes through integrated accessibility planning (as conceptualized in the intensification TLU feedback cycle depicted in figure 2)

4. Conducive to sprawl of land use

5. Conducive to increasing the share of motorized and high-speed transportation

6. Conducive to sprawl of land use and increasing shares of motorized and high-speed transportation

A goal, project, or measure is seen as "conducive to intensification" if it addresses a part of or the whole intensification TLU feedback cycle. If, for example, the goal, project, or measure is directed at increasing density of land use or activities, it contributes to intensification of land use. If a goal, project, or measure is directed at increasing the share of sustainable transportation modes, it is seen as contributing to intensification of the transportation network. A goal, project, or measure that explicitly addresses both halves of the TLU feedback cycle is categorized in the third category. The "expectation" of the effect does not have to be explicitly stated but can also be latently categorized. For example, higher average speeds on the highway network are not explicitly linked to the increase of sprawl, although following the reasoning of Figure 2 they do contribute to sprawl. Codes were subject to constant comparison and constant discovery during the content analysis, as in ethnographic content analysis (Bryman 2001).

Table 1: Types of documents analyzed

\begin{tabular}{|l|c|c|c|}
\hline & National scale & Regional scale & Local scale \\
\hline Development Strategy & 1 & 4 & 1 \\
\hline Regional Agendas & & 3 & \\
\hline
\end{tabular}

During coding, the interpretation of the documents was guided by concrete experiences of the researcher and observation and reflections of practitioners.

The researcher was involved in the implementation of two development strategies. Through "reflective practitioning" (Schön 1984), concrete experiences were linked to concepts from literature. To prevent bias, these concepts were further explored in the interviews. Six practitioners with key roles in trans- 
port and land-use processes from various levels of government were interviewed in a semi-structured way for approximately 60 minutes. From each government level (national, regional, local), two people were interviewed, one from the land-use department and one from the transportation department, but all of them dealing with development strategies and integrated TLU planning. The subject of how intensification affects transportation networks and vice versa and the way development strategies deal with this subject were discussed. They were asked about what happens during the planning process starting with a development strategy and leading to projects or policy actions, with the interviewer prompting questions on "how processes go" and "what do you think is important?" Furthermore, they described if and how "documentary reality" differs from actual reality during this process. Recurring themes were found in the interviews, although from different perspectives. This was seen as sufficient saturation to start with the content analysis.

A possible problem with formal content analysis can be that only manifest content can be found. Through the triangulation of literature, observations, and interviews, latent content was also addressed, providing an in-depth understanding of selected documents

\section{$4 \quad$ Results}

\subsection{Context}

Context for the analysis will be provided by a short introduction of Dutch intensification policies and outcomes.

Under Dutch law, governments on all levels are required to have a development strategy document (a structuurvisie). This is a comprehensive plan or vision that serves as a legal basis for land-use decisions and has a long-term horizon for day-to-day decisions (typically 30 years). The plans mostly consist of a vision and a number of actions to be taken to make the vision reality. There has been a strong tradition in the Netherlands of making these plans since the 1960s and the first national Report on Land Use Planning. Lower-level governments are expected to make their development strategies comply with those of higher-level governments, although there is substantial freedom in choosing otherwise, and more than in the past. The development strategies deal with a broad range of subjects that influence land use, from transportation to climate change to nature conservation.

Investment decisions on large-scale infrastructure and spatial projects are made in the context of a national program, MIRT, in which projects are listed in three phases: exploration, planning, and realization (Ministerie van Infrastructuur en Milieu 2011b). MIRT stands for Meerjarenprogramma Infrastructuur, Ruimte en Transport, translated as Long-Term Program for Infrastructure, Transportation and Land Use. The purpose of the program is "to increase consistency in investment for major land-use and infrastructure projects such as ports, airports, landscaping, public transportation, roads etc."(Ministerie van Infrastructuur en Milieu 2011b). Regional, provincial and national governments engage in periodic negotiations on this program, its projects, and the funding of the projects. The MIRT is an appendix to the national budget, which has to be approved by the national parliament every year.

Since 2009, regional agendas have been a mandatory part of the MIRT process. These regional agendas provide a shared vision of national and regional governments, which leads to a limited long list of possible future projects for the MIRT. The regional agendas are updated permanently (Ministerie van Infrastructuur en Milieu 2011b), so a regional agenda is the result of a collaborative process between various scales and levels of government, with each having its own long-term development strategies. The whole process from development strategies to specific projects is a complex affair, with a large number of stakeholders and decision-making rounds (Teisman 2000). Local and regional governments also initiate numerous small-scale projects and programs of their own, for which a collaborative process with 
national government is not deemed necessary. Table 2 summarizes the main planning documents and actors involved.

Table 2: Status of planning documents in the Netherlands

\begin{tabular}{|l|l|l|}
\hline \multicolumn{1}{|c|}{ Name } & \multicolumn{1}{|c|}{ Development strategies } & \multicolumn{1}{c|}{ Regional agendas } \\
\hline Who? & $\begin{array}{l}\text { Every government level for } \\
\text { its own jurisdiction; lower- } \\
\text { level governments expected } \\
\text { to comply with higher-level } \\
\text { strategies }\end{array}$ & $\begin{array}{l}\text { Collaborative process } \\
\text { between national, regional, } \\
\text { and local governments }\end{array}$ \\
\hline What? & $\begin{array}{l}\text { Plan for long-term (30 years) } \\
\text { land-use development }\end{array}$ & $\begin{array}{l}\text { Plan and long list of } \\
\text { projects }\end{array}$ \\
\hline Legal status & $\begin{array}{l}\text { Legally binding in principle; } \\
\text { exceptions possible }\end{array}$ & None \\
\hline
\end{tabular}

Planning in the Netherlands has aimed for a more compact urban development since the 1980s. This has been done for various reasons, such as preserving open space between the cities, reversing the decline of population in the larger cities, and increasing the modal share of sustainable transportation modes, together forming a complex of interrelated arguments (Boelens and Spit 2011). However, what "compact" exactly meant and if it should be applied to central cities, urban agglomerations, or even larger geographical entities was never specified (Boelens and Spit 2011). Recent spatial development trends are ambivalent. As Figures 3.1 and 3.2 show, the number of new dwellings built within the existing built-up area in 2000 (BUA2000) is lower than dwellings outside of this area, and the number of inhabitants in the existing built-up area declined, while that of those outside increased (Planbureau voor de Leefomgeving 2012). This resulted in a decline of the share of inhabitants inside the BUA2000, from 90.3 percent in 2002 to 86.3 percent in 2010 (Figure 3.3). The share of dwellings inside the BUA2000 declined from 92.3 percent to 89 percent. The same applies for jobs; between 2002 and 2010, the number of jobs within the built-up area stayed constant, while outside of this area jobs rose substantially (Figure 3.4).

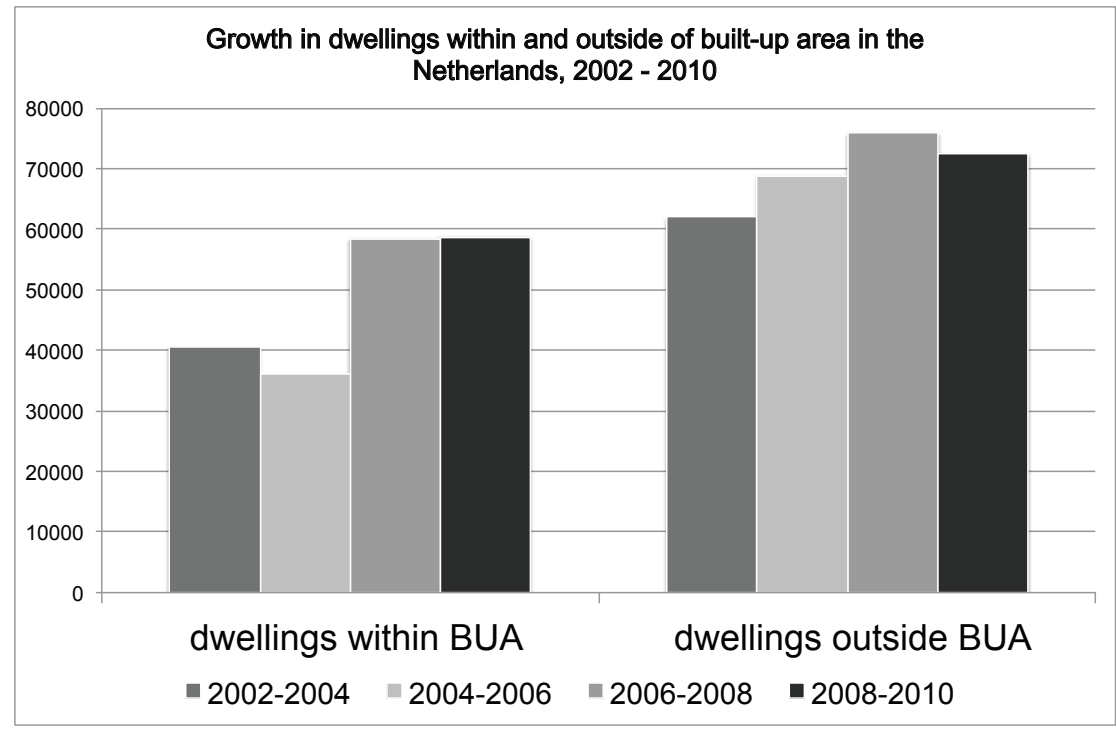

Figure 3.1: Growth in dwellings within and outside of built-up area 
Figure 3.2: Growth in inhabitants within and outside of built-up area

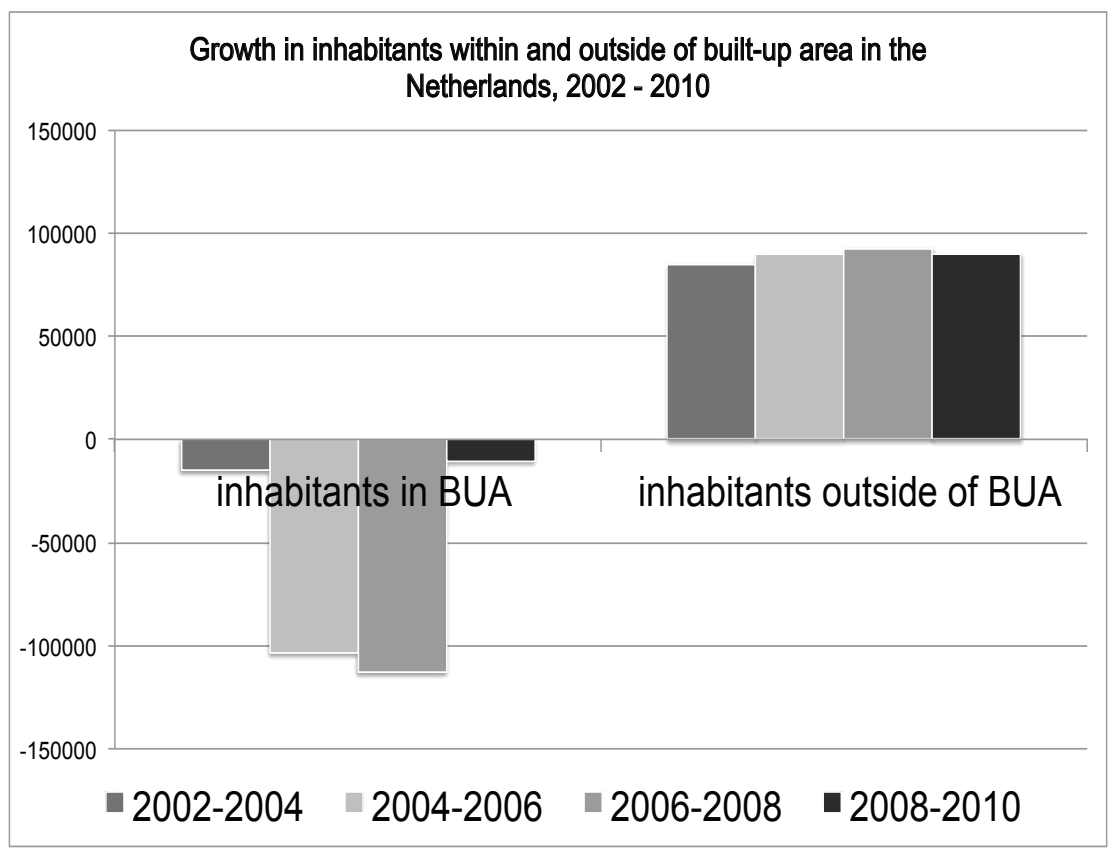

Figure 3.3: Share of inhabitants and dwellings within built-up area

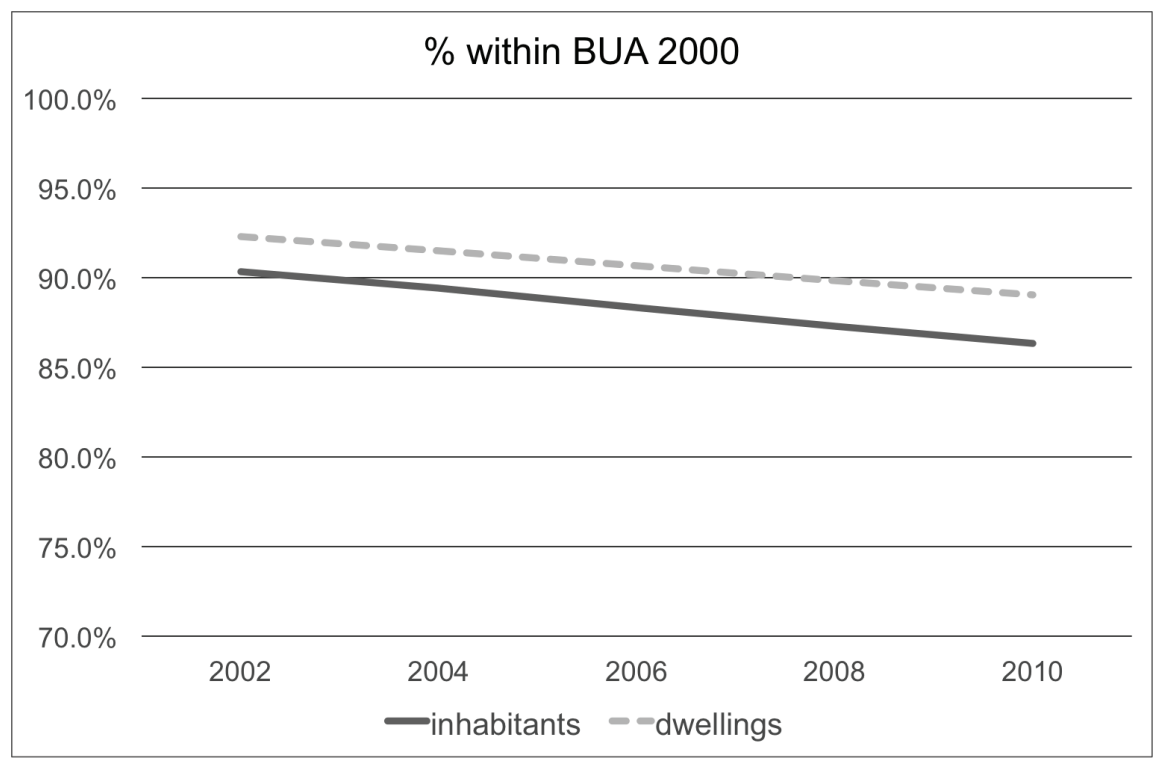




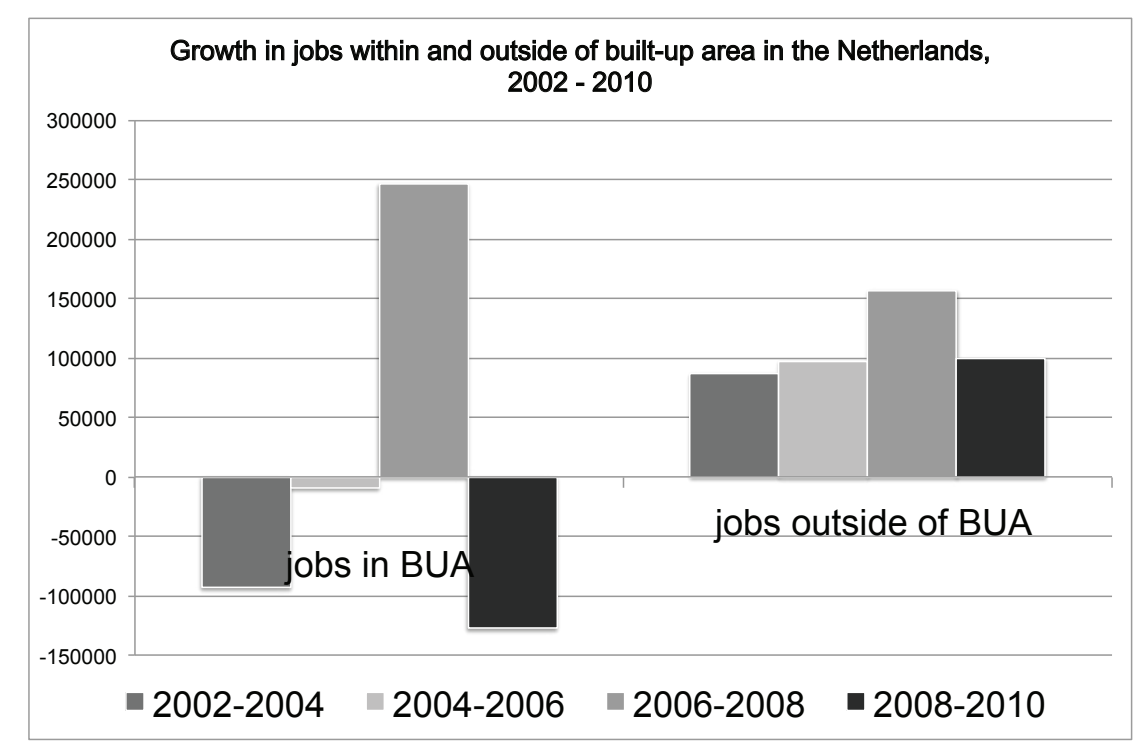

Figure 3.4: Growth in jobs within and outside of built-up area

Source: (Planbureau voor de Leefomgeving 2012)

The Netherlands traditionally has a high share of bicycle use, although there is much differentiation socially and spatially, with the largest and growing share in the cities (Harms, Bertolini, and Te Brömmelstroet 2013). Despite aims of further reducing the share of motorized travel, the modal split at the national level has remained fairly constant over the last 20 years (Figure 4). Furthermore, the total number of trips per person is declining across all modes, while at the same time the average distance per trip is rising across all modes (Figure 5). This indicates that people travel less often to meet their needs, but if travel is needed they travel farther. This corresponds to the idea of peak travel (Millard-Ball and Schipper 2011).

Regional public transport (busses, subway, tram, max 80 kilometers per hour) is used for fairly short trips ( $<13$ kilometers on average), while the national transport network (national railways, max 200 kilometers per hour) is used for fairly long trips (> 40 kilometers on average). 


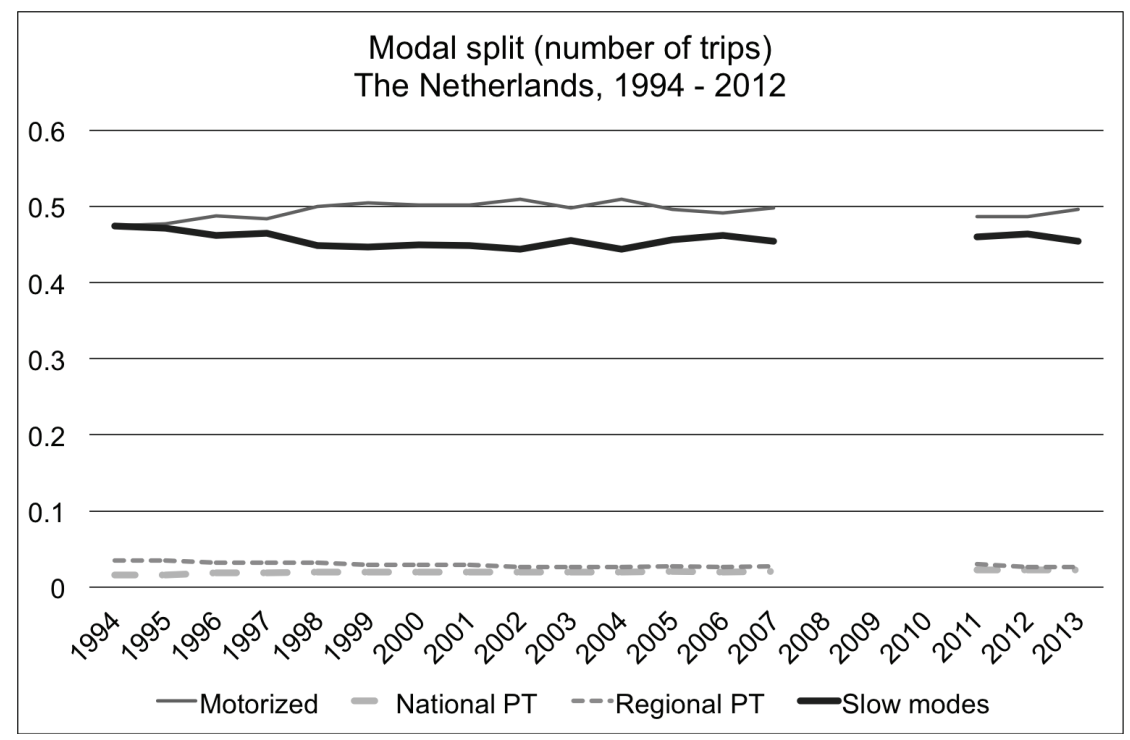

Figure 4: Modal split (number of trips)

Source: Centraal Bureau voor de Statistiek 2014

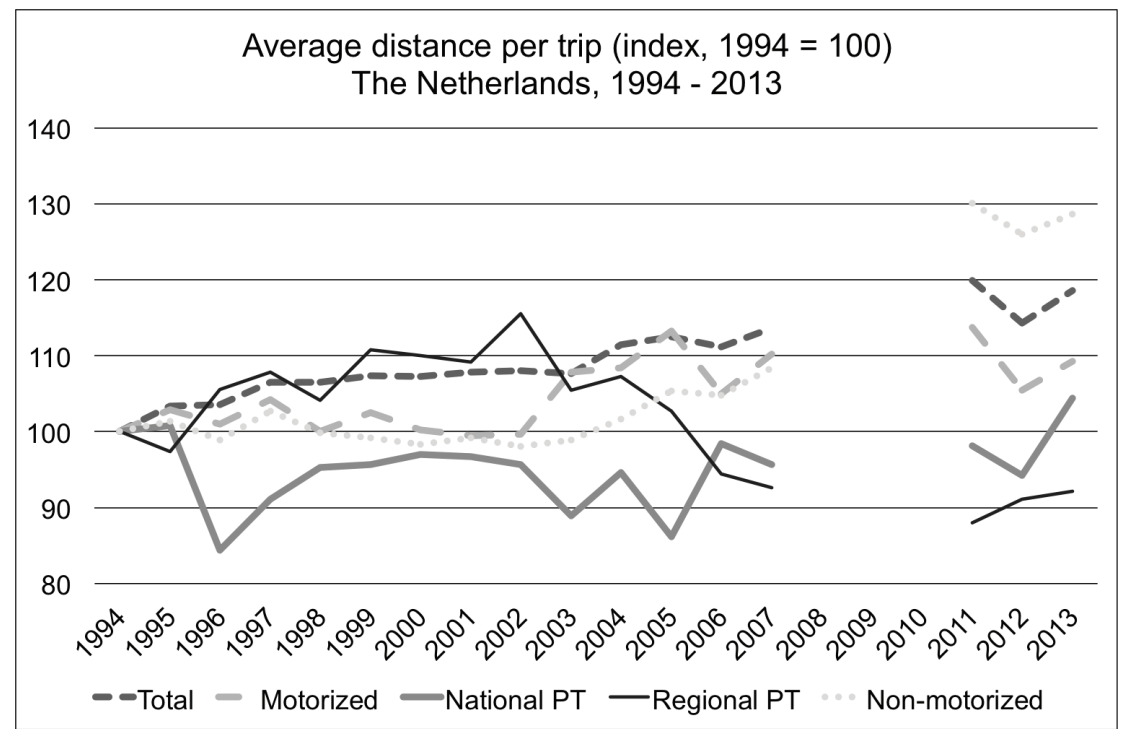

Figure 5: Average length per trip mode in the Netherlands

Source: Centraal Bureau voor de Statistiek 2014

Together, these trends show that population and job growth is largest outside the current built-up area and trips are getting longer on average. In terms of the TLU feedback cycle, a trend toward sprawl can be seen, despite longstanding efforts for more compact city development.

\subsection{Policy aims}

In the documents, analyzed aims are interpreted broadly. Some strategies speak of interests that should be accommodated, others about tasks or challenges the region faces or development directions the re- 
gion should take. What is analyzed here as aims are the elements that structure the strategy and together provide the future image of the region.

The aims mentioned in the strategies are wide-ranging, from "a national ecological network to help flora and fauna survive" (Ministerie van Infrastructuur en Milieu 2012, 27) to "improve competitivity on an international scale" (Provincie Noord-Holland 2011, 42). Recurring themes are climate change, increasing economic competitiveness, preserving open space, and improving accessibility (see Table 2).

Table 3: Number of aims in documents on one of the recurring themes

\begin{tabular}{|l|c|c|c|c|c|c|c|c|c|}
\hline & A & B & C & D & E & F & G & H & I \\
\hline Total number of aims & 13 & 12 & 14 & 3 & 15 & 7 & 5 & 5 & 5 \\
\hline Climate change & 1 & 3 & 1 & & 1 & 1 & 1 & 1 & 1 \\
\hline Economic competitiveness & 1 & 1 & 1 & 1 & 1 & & 1 & 1 & 1 \\
\hline Preserving open space & 1 & 3 & 4 & & 5 & & 1 & 1 & 1 \\
\hline Improving accessibility & 2 & & 3 & 1 & & 2 & 1 & 1 & 1 \\
\hline
\end{tabular}

A = Structuurvisie Infrastructuur en Ruimte, B = Structuurvisie Noord-Holland, C= Structuurvisie Zuid-Holland, D = Regionaal Structuurplan Haaglanden, E = Provinciale Ruimtelijke Structuurvisie, F = Structuurvisie Amsterdam, G = Gebiedsagenda Zuidvleugel, H = Gebiedsagenda Noordwest-Nederland, I = Gebiedsagenda Utrecht

Integrated TLU planning related to intensification can be found in all of the documents. There seems to be widespread recognition of the interplay between intensification and transportation, for example, in these quotes: "Within the multi-modal transportation network, the public transport infrastructure determines where further urbanization can take place. This means an ongoing intensification of urban centers and station areas" (Provincie Zuid-Holland 2012, 44); "Concentration of supraregional services and offices takes place mostly in urban centers, near important public transport nodes" (Provincie Zuid-Holland 2012, 71); "To improve livability and accessibility, inner city growth should be located close to public transportation stops"(Provincie Utrecht 2013, 38). The "intensification paradox" is mentioned a couple of times: "Although intensification will lead to larger shares of public transport use, more car traffic will also occur. Possible new bottlenecks should be carefully examined" (Stadsgewest Haaglanden 2008b, 61); "Land use developments need to take safety and pollution issues into account from the start" (Ministerie van Infrastructuur en Milieu 2012, 123). With the possible exception of the national strategy, the full feedback loop between intensification and sustainable modes seems to be understood and strived for.

However, there are some remarkable findings. The national development strategy does not have intensification as an aim. Other development strategies often mention intensification but mostly as a standalone aim, not related to transportation and not mentioning mix of land uses, only density. Also, although improving public transport and densifying land use around its stations is an aim in nearly all development strategies, slow modes are absent in all but three strategies. This is remarkable regarding the importance of the bicycle in Dutch transportation, with modal shares over 50 percent of all trips in some cities (Fietsberaad 2009).

Most of the time improved transportation is also seen as a standalone aim, without any mention of possible land-use effects. Almost all of the documents have "improving accessibility" as an aim, which is without exception operationalized by capacity and speed increase of the long-distance network of highways and railways. Its direct consequences for land use, i.e., pollution, noise etc., is mentioned but its indirect and long-term consequences for land use, i.e., a further dispersion, is never taken into consideration explicitly.

Concluding, in these development strategies, full "intensification feedback cycles" are recognizable in the documents, meaning that intensification is strived for and transportation and land-use goals 
strengthen each other. However, apart from these integrated aims, a large number of sectorial aims and aims contributing to sprawl can also be found. This corresponds to the lack of explicit focus on compact city development as found by Næss et al. (2009). In particularly, improving highway networks do not strengthen the intensification feedback cycle. For long-distance railway networks, it could be argued that improving highway networks leads to intensification on the local scale of the railway station but to dispersion of activities on the regional scale. This tension between competing aims is not resolved within the strategies, so they are ambivalent on this aspect: striving for intensification and at the same time promoting high-speed transportation network extension.

The regional agendas have a smaller number of aims, ranging from improving the economy to sustainability and climate-proofness. Intensification of the urban area is an aim in every regional agenda. So is improving accessibility. The documents differ less from each other compared to the various development strategies, so the same type of aims are mentioned in every agenda. This implies either horizontal coordination between regions, or vertical coordination of all regions by the national government. The aim of improving accessibility is sometimes related to improvements in public transport, but more often to increases in highway capacity. This means that just as in the development strategies, the competing objectives of both sprawl and intensification are strived for. Although the parts are there, a full "intensification feedback cycle" is harder to find in the regional agendas. However, some projects in the regional agendas are seen as contributing to multiple goals, e.g., economic development and intensification, which implies a more integrated approach.

\subsection{Instruments and actions}

Every development strategy lists a number of actions or projects. The type and number of policy instruments differ greatly between the various development strategies, ranging from a large number of instruments as an integral part of the strategy to the delegation of instruments to follow-up sectoral documents. The development strategies do not have a financial annex, and only for some specific projects are budgets mentioned. For example, one project consists of "prioritizing urban regions over rural regions regarding the available budget for infrastructure"(Ministerie van Infrastructuur en Milieu 2012, 33) without mentioning budget size.

A recurring policy instrument is the "sustainable urbanization ladder" for land-use development. This is mentioned by all strategies and is being laid down in national legislation. This ladder consists of three questions that need to be answered in decision-making on future development:

1. Does the development meet present market demand?

2. Can it be realized through transformation of the existing built-up area?

3. If not, can it be realized on a location accessible by multiple transportation modes?

If the answer to all three questions is no, a planning permit should not be awarded. All documents acknowledge extensively that this requires strong horizontal and vertical policy coordination.

For the regional agendas, providing long lists of projects is their main purpose. Transportation projects are more frequently listed compared to land-use projects. Although the sectoral categories are similar in all regional agendas, the number of projects and what is defined as a project differs among various agendas. Some agendas list specific location developments as a separate project. The transportation projects are mostly very specific, with definitions such as "connecting the A28 and A30 highways" (Rijksoverheid et al. 2009, 52), while the land-use projects are more generally worded, as in "integrated development of station areas." Furthermore, projects concerning high-speed networks (especially car) take prominence over smaller-scale policy actions (dealing either with local and regional public transport and slow modes, or with land use). Slow modes are once again almost absent. 


\subsection{Measuring and monitoring}

The development strategies mention different kinds of indicators by which to assess whether mentioned goals are reached, including:

- Climate related (reduction in greenhouse gas emissions)

- Land-use related (percent and numbers of dwellings and offices to be built)

- Transportation related (minimum average speeds, minimum railway frequencies, minimum rise in kilometers traveled by slow modes and public transport)

Climate-related indicators are mostly stated in a broad sense, as in, for example, "60 percent reduction in $\mathrm{CO}_{2}$ emissions" (Ministerie van Infrastructuur en Milieu 2012, 23), "climate neutral province by 2040 " (Provincie Utrecht 2013, 12), or "production of 60 Megawatts of wind power before 2020" (Ministerie van Infrastructuur en Milieu 2012, 9). None of them are made specific for transportation, although some documents acknowledge transportation causes a large and growing part of $\mathrm{CO}_{2}$ emissions.

All regional-level development strategies have quantified goals for intensification in a relative sense, stating that "x percent of new housing and offices should be built within the existing built-up area," with the number ranging from 50 percent in rural areas to 80 percent in the urbanized part of the province of South Holland (Provincie Zuid-Holland 2012, 44). Virtually all regional development strategies also mention the absolute number of dwellings "needed" to address present and future housing demand. Only in the province of South Holland are these figures linked to transportation, by stating that 40 percent of new dwellings should be located within 1200 meters of railway stations (Stadsgewest Haaglanden 2008a, 69). For the other regions, the quantitative targets agreed to are based on spatial capacity, which is not contingent on transportation. The local and the national development strategies do not provide indicators for intensification.

Some development strategies not only have very quantitative goals on the number of dwellings, but also on the area needed for offices and business parks. In one case, this is a negative indicator, requiring transformation of existing office parks into residential areas.

The national government mentions the largest number of transportation indicators. Mobility growth needs to be provided for in all circumstances. Car traffic is expected to grow by $20-25$ percent by 2020 and public transport by $25-30$ percent. One indicator states the minimum number of lanes on a highway, depending on the amount of expected traffic and the economic importance of the area. Some long-standing indicators, dating from previous development strategies, are reconfirmed, such as "average minimum speed on the highway network should be 80 kilometers per hour or more," or "peak hour travel times should not exceed free-flow travel time by a factor 1.5, and by a factor 2 around the five largest cities." Also, minimum train frequencies on specific corridors are mentioned (e.g., "12 trains per hour"). Some regional development strategies incorporate these goals, but most are less specific on transportation indicators, even if they list specific projects, roads, or railroads. Only The Hague regional development strategy has quantified the goal of improved use of public transport and slow modes in an indicator: "Before 2030, bicycle use (trips made) and public transport use (passenger numbers) should have risen by 50 percent" (Stadsgewest Haaglanden 2008a, 121).

The regional agendas comply mostly with the national-level indicators on transportation, since they are co-produced by the national government. So, the same minimum average speeds and train frequencies can be seen as in the national development strategies. This indicates an attempt at vertical coordination by the national government. In the following table, an overview of indicators is given. Some of the indicators and aims are shared by all three regional agendas, while some are specific for one region. The way the indicators and aims are given can be analyzed in terms of the intensification/sprawl feedback cycle. In Table 4, per indicator, an analysis is made if moving toward the stated aim contributes to intensification or to sprawl or both. 
Table 4: Indicators used in regional agendas

\begin{tabular}{|c|c|c|c|c|}
\hline Indicator/goal & S-H & N-H & $\mathbf{U}$ & $\begin{array}{c}\text { Contributes to sprawl } \\
\text { or intensification }\end{array}$ \\
\hline Number of new dwellings before 2020 & 175.000 & 175.000 & 100.000 & depends on location \\
\hline $\begin{array}{l}\text { Percent of new dwellings within existing } \\
\text { built-up area }\end{array}$ & 80 & $\mathrm{x}$ & 67 & intensification \\
\hline $\begin{array}{l}\text { Trains per hour per direction on main } \\
\text { corridors }\end{array}$ & 12 & 12 & 10 & depends on location \\
\hline $\begin{array}{l}\text { Specific road, railroad or public transport } \\
\text { projects }\end{array}$ & multiple & multiple & multiple & depends on location \\
\hline $\begin{array}{l}\text { Average speed on main roads } 80 \mathrm{~km} / \mathrm{h} \\
\text { during peak hours }\end{array}$ & yes & yes & yes & sprawl \\
\hline Less supply of office space & no & $3.500 .000 \mathrm{~m} 2$ & no & depends on location \\
\hline New jobs & no & $\begin{array}{c}110.000 \text { (in sprawl } \\
\text { locations) }\end{array}$ & no & sprawl \\
\hline $\begin{array}{l}\text { Percentage of dwellings that should be social } \\
\text { housing }\end{array}$ & no & 30 & no & unspecified \\
\hline Maximum housing shortage & no & no & $1.5 \%$ & unspecified \\
\hline Percentage of CO 2 reduction by 2020 & no & 20 & no & unspecified \\
\hline $\begin{array}{l}\text { Percentage less energy use by currently exist- } \\
\text { ing dwellings }\end{array}$ & no & no & 30 & unspecified \\
\hline $\begin{array}{l}\mathrm{m}^{2} \text { open space outside built-up area per new } \\
\text { dwelling }\end{array}$ & no & no & 75 & intensification \\
\hline $\begin{array}{l}\text { Percentage of built-up area that should be } \\
\text { playground }\end{array}$ & no & no & 3 & unspecified \\
\hline Hectares of new industrial areas & no & no & 750 & sprawl \\
\hline Hectares of new nature & no & no & 11.000 & intensification \\
\hline
\end{tabular}

$\mathrm{S}-\mathrm{H}$ is Province of South-Holland, N-H is province of North-Holland and Flevoland, U is province of Utrecht

The impacts of the goals differ. Generally speaking, land-use goals contribute to intensification because of the minimum percentages of new dwellings that need to be built within the existing built-up area. However, tensions exist between these "relative" goals and the absolute goals of building large numbers of new dwellings, creating new jobs, and locating a large share of new dwellings near railway stations (which are not necessarily within the existing built-up area). Transportation goals point in the direction of sprawl. Minimum speeds on the whole network and specific projects to extend the high-speed networks are very prominent throughout both the development strategies and the regional agendas.

The monitoring of progress toward the achievement of the goals is done in various ways. Some directly translate policy goals, indicators, and actions into monitoring their progress. This is done extensively by the national government and the province of South Holland. All other development strategies are not monitored explicitly, although some of the indicators and goals can be found in sectoral monitoring documents not linked to the development strategies. The regional agendas are not monitored at all. Although a large number of actions, measures, or projects are proposed, leading directly to different output and outcomes, there is no comprehensive monitoring that provides insight into how these outputs and outcomes develop. Data is available in various guises, in various organizations, and in various projects, but not comprehensively or related to the regional agenda. 


\subsection{Reflections}

Apart from providing themes for the content analysis, the interviews and participant observations provided some interesting reflections in their own right. They are presented here to provide further depth to the content analysis and directions for further research.

Interviewees state that actors involved underline the necessity for integrated TLU planning and act accordingly in the strategic planning phase in which general development strategies are made. However, in the everyday practice that follows these strategies, actors focus on their own individual responsibilities. The development strategy is just "one of many policy areas"(Marsden et al. 2014, 13). Actors act strategically depending on how parts of the development strategy influence their own agenda and responsibilities. As soon as general goals need to be implemented through specific policy actions or projects, other considerations that were left outside of the strategic planning process show up. Characteristic comments include: "If intensification means more congestion on our road network, we might not want it after all," or "We want more users of our public transport system; let's support intensification around railway stations, even if they are outside of the built-up area." Interviewers mention no apparent mechanism or accountability framework that urges or incentivizes actors to plan for intensification in an integrated way after the strategic plan has been agreed on.

Funding for infrastructure mostly comes from the national government, so the indicators and aims are adopted by regional and local governments in competition for national funding. This leads to the effect that accessibility goals and actions are mostly perceived from a regional, if not national, rather than a local scale. Transport planners seem to focus on large-scale high-speed networks and have a large number of sophisticated planning tools to analyze these when making strategic plans. These are generally largescale infrastructure projects, extending high-speed networks instead of contributing to intensification. This might be caused by "infrastructuralism” (Olesen 2013; Marshall 2013).

Despite the large modal share of the bicycle, it is almost absent in strategic planning. It is seen as something that "always fits" and doesn't need strategic choices, so is only relevant after the general development strategies have been made. The mounting congestion and capacity issues related to a surge in bicycle use in central cities, however, seem to question these assumptions. Due to the focus on highspeed networks and the lack of attention to slow modes, the documents are ambiguous (Næss, Næss, et al. 2011) on transport policy.

It can be argued that this ambiguity counteracts intensification and the TLU feedback cycle. Intensification is not only about large-scale, one-off land use or infrastructural projects. If these are not coordinated, they might even be counterproductive. Lots of reciprocally reinforcing small interventions, both on the land use and the transportation side of the feedback cycle, may also make intensification possible, and perhaps even most importantly so.

\section{Conclusion}

Content analysis shows that the full intensification feedback cycle is a major aim of the development strategies of Dutch governments. Also, in the regional agendas and long lists of projects, there are interventions that deal with intensification and transportation planning in an integrated way. So, "significant commitment to many of the principles that enable the integration of transport and land use" (Curtis and Armstrong 2009) can be found. However, there are contrasting goals that lead to sprawl through increasing capacity and reach of high-speed networks. Also, there seems to be little consideration on the contribution of slow modes or the mixing of land uses for achieving strategic aims.

When moving from policy aims to specific policy actions, fragmentation occurs and actions are formulated sectorally. Although there are various actions that contribute to a full intensification feedback 
cycle, a larger number of actions don't. They either deal with fragmented parts of the cycle, or counteract intensification, or both.

Regarding the indicators and monitoring mentioned, this fragmentation increases. Quantified indicators deal with outputs regarding land use on the one side, and the transportation network on the other side. Indicators are mostly directed at providing land for growth and increasing speeds and frequencies on the transportation network. There are only a very limited number of indicators dealing with using existing built-up areas more efficiently, or providing for accessibility needs by means of proximity and slow modes. Monitoring of these indicators is often fragmented in itself, being delegated to sectoral sub-documents instead of the general development strategy. Regional governments mostly monitor land-use developments and comply with national-level transportation indicators. This does confirm that performance measures do not converge toward a single goal, as also found by Miller and Evans (2011).

For the "intensification feedback cycle" to be implemented in the planning process in the Netherlands, two moments seem crucial. The first is when the policy aims have been set and actions or instruments have to be defined. The analysis shows that the latter often conflict with the former, or at best are fragmented. Second, when indicators have been put in place, and a feedback loop to the achievement of the original, comprehensive aims needs to be established; the analysis shows that this feedback is lacking. The two reinforce each other; it is not seen as necessary to have integrated actions and instruments, since monitoring is not integrated, or if it is, results will not be fed back into the planning process.

By focusing on the inconsistencies and contradictions in these two steps, on how and why they emerge, institutional barriers to intensification might be better understood and possibly overcome. This provides a focus for further research.

As for the implications of the findings for other contexts, the following applies. As mentioned in the Introduction, the Netherlands can be characterized as a critical case in that this implementation gap is also likely to be present in countries with a lower, less explicit commitment to urban intensification and TLU planning integration. While this assumption would need, of course, to be verified in these other contexts, the analysis in this paper provides some cues. Most importantly, it is essential to extend the analysis to all phases of the planning process. Only by identifying when the implementation gap emerges, can we understand where the problem precisely lies, what might cause it, and what might address it. The latter does not need to be easy. As we have seen in the Dutch case, the lack of consistency might reflect the existence of unsolved conflicts around the aims, or of deep-seated institutional fragmentation. In any event, just assuming that the adoption of intensification and transport and land-use integration as a strategic policy aim is a guarantee that it is followed up in the rest of the planning process will not do. Some of the most crucial, and perhaps most difficult choices, are to be made further down the line. The work of others seems also to point in this direction (Handy 2008; Miller and Evans 2011) 


\section{References}

Aditjandra, P. T., X. Cao, and C. Mulley. 2012. Understanding neighborhood design impact on travel behavior: An application of structural equations model to a British metropolitan data. Transportation Research Part A: Policy and Practice 46(1): 22-32. http://linkinghub.elsevier.com/retrieve/pii/ S0965856411001340.

Banister, D. 2008. The sustainable mobility paradigm. Transport Policy 15(2): 73-80. http://linkinghub. elsevier.com/retrieve/pii/S0967070X07000820.

Bertolini, L., and F. Le Clercq. 2003. Urban development without more mobility by car? Lessons from Amsterdam, a multimodal urban region. Environment and Planning A 35(4): 575-589. http://www. envplan.com/abstract.cgi?id=a3592.

Boelens, L., and T. Spit. 2011. Tussen droom en daad staat weinig regelmaat. In Compacte Stad Extended, edited by L. Boelens, H. Ovink, H. Palsdottir, and E. Wierenga. 106-125. Rotterdam: 010 Publishers.

Brownstone, D., and T. F. Golob. 2009. The impact of residential density on vehicle usage and energy consumption. Journal of Urban Economics 65(1): 91-98. http://linkinghub.elsevier.com/retrieve/pii/ S0094119008001095.

Bryman, A. 2001(2008). Social research methods (3rd ed.). Oxford: Oxford University Press.

Centraal Bureau voor de Statistiek. 2014. Onderzoek Verplaatsingsgedrag in Nederland. http://statline. cbs.nl.

Cervero, R. 1998. The Transit Metropolis, Washington, DC: Island Press.

Cervero, R., and J. Day. 2008. Suburbanization and transit-oriented development in China. Transport Policy 15(5): 315-323. http://linkinghub.elsevier.com/retrieve/pii/S0967070X08000577.

Cervero, R., and M. Duncan. 2008. Which reduces travel more: jobs-housing balance or retail-housing mixing? Journal of the American Planning Association 72(4): 475-490.

Curtis, C. 2008. Planning for sustainable accessibility: The implementation challenge. Transport Policy 15(2): 104-112. http://linkinghub.elsevier.com/retrieve/pii/S0967070X07000868.

Curtis, C., and R. Armstrong. 2009. The capacity of state and local government to deliver sustainable and integrated transport: The case of transit oriented development in Perth, Australia. International Scholarly and Scientific Research \& Innovation 3(6):119-135.

Ewing, R., and R. Cervero. 2010. Travel and the built environment. Journal of the American Planning Association 76(3): 265-294. http://www.tandfonline.com/doi/abs/10.1080/01944361003766766.

Ewing, R., and R. Cervero. 2001. Travel and the built environment: A synthesis. Transportation Research Record 1780(01).

Ferreira, A., and P. Batey. 2011. On why planning should not reinforce self-reinforcing trends: A cautionary analysis of the compact-city proposal applied to large cities. Environment and Planning B: Planning and Design 38(2): 231-247. http://www.envplan.com/abstract.cgi?id=b36102.

Fietsberaad. (2009). Het fietsbeleid van de Europese toppers: langdurig en integraal. Publication number 7. Utrecht, Fietsberaad.

Gaffron, P. (2002). Synthesis Report: Implementation. Planning and Urban Mobility in Europe (PLUME): European Commission.

Handy, S., 2005. Smart growth and the transportation-land use connection: What does the research tell us? International Regional Science Review 28: 146-167.

Harms, L., L. Bertolini, and M. Te Brömmelstroet. 2013. Social and spatial differentiation of bicycle use patterns in the Netherlands. In World Conference on Transport Research, Rio de Janerio Brazil, July $15-18,2013$. 
Hull, A. 2005. Integrated transport planning in the UK: From concept to reality. Journal of Transport Geography 13(4): 318-328. http://linkinghub.elsevier.com/retrieve/pii/S0966692305000062.

Hull, A. 2008. Policy integration: What will it take to achieve more sustainable transport solutions in cities? Transport Policy 15(2): 94-103. http://linkinghub.elsevier.com/retrieve/pii/S0967070X07000844.

Hull, A. 2011. Transport Matters. London/New York: Routledge.

Krizek, K.J., and D. Levinson. 2008. Planning for Place and Plexus: Metropolitan Land Use and Transport. New York: Routledge.

Marshall, T. 2013. Planning Major Infrastructure: A Critical Analysis. New York: Routledge. http://www. routledge.com/books/details/9780415669559/.

Melia, S., G. Parkhurst, and H. Barton. 2011. The paradox of intensification. Transport Policy 18(1): 46-52. http://linkinghub.elsevier.com/retrieve/pii/S0967070X10000752.

Millard-Ball, A., and L. Schipper. 2011. Are we reaching peak travel? Trends in passenger transport in eight industrialized countries. Transport Reviews 31(3) 357-378. http://www.tandfonline.com/doi/ abs/10.1080/01441647.2010.518291.

Miller, J. S., and L. D. Evans. 2011. Divergence of potential state-level performance measures to assess transportation and land use coordination. Journal of Transport and Land Use 4(3): 81-103. https:// www.jtlu.org/index.php/jtlu/article/view/96.

Ministerie van lenM - Infrastructuur en Milieu (2012) Structuurvisie Infrastructuur en Ruimte, [National Policy Strategy for Infrastructure and Spatial Planning] Den Haag. Ministerie van lenM.

Næss, P., A. Strand, T. Næess, and M. Nicolaisen 2011a. On their road to sustainability? Town Planning Review 82 (April 2010).

Næss, P., A. Strand, T. Næss, and M. Nicolaisen. 2011. On their road to sustainability? The challenge of sustainable mobility in urban planning and development in two Scandinavian capital regions. Town Planning Review 82(3): 285-315. doi: 10.3828/tpr.2011.18.

Næss, P. 2005. Residential location affects travel behavior? But how and why? The case of Copenhagen metropolitan area. Progress in Planning 63(2): 167-257. http://linkinghub.elsevier.com/retrieve/pii/ S0305900604000583.

Næss, P., T. Næss, M. S. Nicolaisen, and E. Clemens. (2009). The challenge of sustainable mobility in urban planning and development in Copenhagen Metropolitan Area. (2nd ed.) Aalborg: Institut for Samfundsudvikling og Planlægning, Aalborg Universitet. (ISP-Skriftserie; No. 2009-5).

Næss, P., T. Næss, and A. Strand. 2011. Oslo's Farewell to Urban Sprawl. European Planning Studies 19(1): 113-139. http://www.tandfonline.com/doi/abs/10.1080/09654313.2011.530395.

Niemeier, D., S. Bai, and S. Handy. 2011. The impact of residential growth patterns on vehicle travel and pollutant emissions. Journal of Transport and Land Use 4(3): 65-80. https://www.jtlu.org/index. $\mathrm{php} / \mathrm{jtl}$ / /article/view/226.

Olesen, K. 2013. Strategic spatial planning's role in legitimizing investments in transportation infrastructure. In AESOP-ACSP Joint Congress, July 15-19 2013, University College Dublin, Dublin Ireland.

Petersen, M.S., R. Enei, C. O. Hansen, E. Larrea, O. Obisco, C. Sessa, P. M. Timms, A. Ulied. 2009. Report on Transport Scenarios with a 20 and 40 Year Horizon. Final Report. Funded by DG TREN, Copenhagen, Denmark.

Kuiper, R. J. van der Schuit, 2012. Monitor Infrastructuur en Ruimte; nulmeting. Den Haag: Planbureau voor de Leefomgeving.

Provincie Noord-Holland. 2011. Structuurvisie Noord-Holland 2040. http://www.noord-holland.nl/ web/Themas/Ruimtelijke-ordening/Structuurvisie.htm

Provincie Utrecht. 2013. Provinciale Ruimtelijke Structuurvisie. https://www.provincie-utrecht.nl/ 
onderwerpen/alle-onderwerpen/provinciale-0/provinciale/

Provincie Zuid-Holland. 2012. Provinciale Structuurvisie (inclusief eerste herziening en actualisering).

Rijksoverheid et al. 2009. Gebiedsagenda Utrecht. https:/www.provincie-utrecht.nl/publish/pages/195371/gebiedsagenda_utrecht_2009_november_2009.pdf.'https://www.provincie-utrecht.nl/ publish/pages/195371/gebiedsagenda_utrecht_2009_november_2009.pdf.

Schön, D. 1984. The Reflective Practitioner: How Professionals Think in Action. New York: Basic Books.

Schwanen, T., F. M. Dieleman, and M. Dijst. 2004. The impact of metropolitan structure on commute behavior in the Netherlands: A multilevel approach. Growth and Change 35(3): 304-333. http://doi. wiley.com/10.1111/j.1468-2257.2004.00251.x.

Stadsgewest Haaglanden. 2008a. Regionaal Structuurplan Haaglanden 2020: Uitwerking van de visie, The Hague.

Stadsgewest Haaglanden. 2008b. Regionaal Structuurplan Haaglanden 2020; Visie.

Stead, D., H. Geerlings, and E. Meijers. 2004. Policy integration in practice. Delft: DUP Science.

Straatemeier, T. 2008. How to plan for regional accessibility? Transport Policy 15(2): 127-137. http:// linkinghub.elsevier.com/retrieve/pii/S0967070X07000856.

Timms, P. 2011. Urban transport policy transfer: Bottom-up and top-down perspectives. Transport Policy 18(3): 513-521. http://linkinghub.elsevier.com/retrieve/pii/S0967070X10001332.

UNEP. 2013. Global Environmental Outlook 5. http://www.unep.org/geo/geo5.asp.

van Wee, B. 2011. Evaluating the impact of land use on travel behavior: The environment versus accessibility. Journal of Transport Geography 19(6): 1530-1533. http://www.sciencedirect.com/science/ article/pii/S0966692311000743.

Wheeler, S. 2009. Regions, Megaregions, and Sustainability. Regional Studies 43(6): 863-876. http:// www.tandfonline.com/doi/abs/10.1080/00343400701861344. 